\title{
GUCY1A2 wt Allele
}

National Cancer Institute

\section{Source}

National Cancer Institute. GUCY1A2 wt Allele. NCI Thesaurus. Code C52036.

Human GUCY1A2 wild-type allele is located within 11q21-q22 and is approximately $331 \mathrm{~kb}$ in length. This allele, which encodes guanylate cyclase soluble subunit alpha-2 protein, is involved in cyclic GMP biosynthesis and nitric oxide binding. 